\title{
Subunit-Specific Association of Protein Kinase C and the Receptor for Activated C Kinase with GABA Type A Receptors
}

\author{
Nicholas J. Brandon, ${ }^{1}$ Julia M. Uren, ${ }^{1}$ Josef T. Kittler, ${ }^{1}$ Hongbing Wang, ${ }^{2}$ Richard Olsen, ${ }^{2}$ Peter J. Parker, ${ }^{3}$ \\ and Stephen J. Moss ${ }^{1}$ \\ ${ }^{1}$ Medical Research Council Laboratory of Molecular Cell Biology and Department of Pharmacology, University College \\ London, London WC1E 6BT, United Kingdom, ${ }^{2}$ Department of Pharmacology, University of California at Los Angeles \\ School of Medicine, Los Angeles, California 90024, and 3/mperial Cancer Research Fund, London WC2A 3PX, \\ United Kingdom
}

\begin{abstract}
GABA receptors $\left(\mathrm{GABA}_{\mathrm{A}}\right)$ are the major sites of fast synaptic inhibition in the brain and can be assembled from five subunit classes: $\alpha, \beta, \gamma, \delta$, and $\epsilon$. Receptor function can be regulated by direct phosphorylation of $\beta$ and $\gamma 2$ subunits, but how kinases are targeted to $\mathrm{GABA}_{\mathrm{A}}$ receptors is unknown. Here we show that protein kinase C- $\beta$ II (PKC- $\beta$ II) is capable of directly binding to the intracellular domain of the receptor $\beta 1$ and $\beta 3$ subunits, but not to those of the $\alpha 1$ or $\gamma 2$ subunits. Moreover, associating PKC- $\beta$ II is capable of specifically phosphorylating serine 409 in $\beta 1$ subunit and serines $408 / 409$ within the $\beta 3$ subunit, key residues for modulating $\mathrm{GABA}_{A}$ receptor function. The receptor for activated $C$ kinase (RACK-1) was found also to bind to the $\beta 1$ subunit intracellular domain, but PKC binding appeared to
\end{abstract}

$\mathrm{GABA}_{\mathrm{A}}$ receptors are the major sites of fast synaptic inhibition in the brain (Macdonald and Olsen, 1994; Rabow et al., 1995). $\mathrm{GABA}_{\mathrm{A}}$ receptors are part of a ligand-gated ion channel superfamily whose members include nicotinic acetylcholine, glycine, and $5 \mathrm{HT}_{3}$ receptors (Unwin, 1993). Members of this channel superfamily are believed to be heteropentamers, the subunits of which share a common transmembrane topology. This comprises a large $\mathrm{N}$-terminal domain and four transmembrane domains (TMs) with a major intracellular domain between TMs 3 and 4 (Unwin, 1993). $\mathrm{GABA}_{\mathrm{A}}$ receptor subunits can be divided into five subunit classes with multiple members: $\alpha(1-6), \beta(1-3), \gamma(1-3), \delta$, and $\epsilon$ (Macdonald and Olsen, 1994; Rabow et al., 1995). Heterologous expression has revealed that the coexpression of receptor $\alpha, \beta$, and $\gamma$ subunits reproduces many of the physiological and pharmacological properties of neuronal GABA ${ }_{\mathrm{A}}$ receptors (Macdonald and Olsen, 1994; Rabow et al., 1995).

There is considerable interest in understanding the molecular mechanisms used by neurons to regulate $\mathrm{GABA}_{\mathrm{A}}$ receptor function, with much emphasis at present focusing on the role of receptor phosphorylation. Studies on recombinant receptors have revealed that receptor $\beta$ and $\gamma$ subunits are the substrates of a range of protein kinases (Moss and Smart, 1996). Specifically, the $\beta 1-3$ subunits are phosphorylated on a conserved serine residue

\footnotetext{
Received June 3, 1999; revised July 22, 1999; accepted Aug. 13, 1999.

This work was supported by the Medical Research Council (UK) and the Wellcome trust.

Correspondence should be addressed to Dr. Stephen J. Moss, MRC-LMCB, University College, Gower Street, London WC1E 6BT. Email: steve.moss@UCL.ac.uk. Copyright (C) 1999 Society for Neuroscience $0270-6474 / 99 / 199228-07 \$ 05.00 / 0$
}

be independent of this protein. Using immunoprecipitation, the association of PKC isoforms and RACK-1 with neuronal GABA receptors was seen. Furthermore, PKC isoforms associating with neuronal receptors were capable of phosphorylating the receptor $\beta 3$ subunit.

Together, these observations suggest $\mathrm{GABA}_{\mathrm{A}}$ receptors are intimately associated with PKC isoforms via a direct interaction with receptor $\beta$ subunits. This interaction may serve to localize PKC activity to $\mathrm{GABA}_{A}$ receptors in neurons allowing the rapid regulation of receptor activity by cell-signaling pathways that modify PKC activity.

Key words: $G A B A_{A}$ receptor; $\beta$ subunit; PKC; RACK-1; intracellular domain; protein kinase $C$

(S409 or S410) by PKC, whereas PKA will differentially phosphorylate $\beta$ subunits on S409 in vivo (Moss et al., 1992a,b; Krishek et al., 1994; McDonald and Moss, 1997; McDonald et al., 1998). There are additional phosphorylation sites for PKC, $\mathrm{Ca}^{2+}$-calmodulin type 2 dependent protein kinase (Cam KII) and cGMP-dependent protein kinase (PKG) within the $\beta 1, \beta 3$, and $\gamma 2$ subunits (Moss et al., 1992a; McDonald and Moss 1994, 1997). The prototypic tyrosine kinase SRC will also phosphorylate specific sites within the $\gamma 2$ and $\beta 1$ subunits (Moss et al., 1995). In agreement with these observations, purified preparations of neuronal $\mathrm{GABA}_{\mathrm{A}}$ receptors are phosphorylated in vitro by PKA, PKC, and SRC (Kirkness et al., 1989; Browning et al., 1990; Valenzuela et al., 1995). GABA receptor phosphorylation can cause diverse functional effects, ranging from enhancements to inhibitions depending on the identity and location of the sites phosphorylated (Kapur and Macdonald, 1996; Lin et al., 1996; Moss and Smart, 1996; McDonald et al., 1998).

Although much progress has been made on identifying which receptor subunits are kinase substrates, little is presently understood regarding how specific kinases are targeted to $\mathrm{GABA}_{\mathrm{A}}$ receptors to ensure subunit-specific phosphorylation. To further investigate this, we have used subunit intracellular domains to look for interacting molecules that mediate $\mathrm{GABA}_{\mathrm{A}}$ receptor phosphorylation. Here we demonstrate that PKC- $\beta$ II is targeted to $\mathrm{GABA}_{\mathrm{A}}$ receptors via a direct interaction with receptor $\beta$ subunits that is independent of the receptor for activated $\mathrm{C}$ kinase (RACK-1). Both PKC and RACK-1 immunoprecipitate with $\mathrm{GABA}_{\mathrm{A}}$ receptors from cortical neurons. In addition, PKC isoforms associating with neuronal $\mathrm{GABA}_{\mathrm{A}}$ receptors are capable of phosphorylating the receptor $\beta 3$ subunit. Together our obser- 
vations suggest a critical role of receptor $\beta$ subunits in targeting $\mathrm{PKC}$ activity to $\mathrm{GABA}_{\mathrm{A}}$ receptors.

\section{MATERIALS AND METHODS}

Production and purification of fusion proteins. The major intracellular loop between TM3 and TM4 of the $\mathrm{GABA}_{\mathrm{A}}$ receptors $\alpha 1, \beta 1, \beta 2, \beta 3$, and the "short" form of the $\gamma 2$ subunit ( $\gamma 2 \mathrm{~s}$; Whiting et al., 1990; Kof uji et al., 1991) were cloned as BamHI-EcoRI fragments into pGex-4T3 (Pharmacia, Piscataway, NJ), for the production of glutathione- $S$ transferase (GST) fusion proteins. An EcoRI-SmaI fragment comprising the entire coding sequence of RACK-1 was subcloned into pGEX-2TK. (Pharmacia). The RACK-1 cDNA was a kind gift of D. Mochly-Rosen, Stanford University (Ron et al., 1994). DNA constructs, the fidelity of which had been verified by DNA sequencing, were transformed into Escherichia coli strain BL21 for protein expression. One liter cultures were grown, induced with isopropyl-B-D-thiogalactoylpyranoside (0.1 $\mathrm{mM}$ ), sonicated, and the GST fusion proteins were then purified on glutathione agarose beads (Sigma, St. Louis, MO) as described previously (Smith and Johnson, 1988; Moss et al., 1992b).

Affinity purification "pull-down" assays. Brains from adult Sprague Dawley rats were homogenized in buffer containing $1 \%$ Nonidet P-40, $0.5 \%$ deoxycholate, and (in $\mathrm{mm}$ ) $150 \mathrm{NaCl}, 10$ triethanolamine, $\mathrm{pH} 7.6$, 5 EGTA, 5 EDTA, $50 \mathrm{NaF}, 1 \mathrm{Na}$ orthovanadate, $100 \mathrm{PMSF}$, and 10 $\mu \mathrm{g} / \mathrm{ml}$ leupeptin, pepstatin, antipain, and aprotinin. Insoluble material was removed by centrifugation at $50,000 \times g^{\mathrm{K}}$ for $30 \mathrm{~min}$. Extracts $(5 \mathrm{mg}$ of protein) were then exposed to receptor fusion proteins $(20 \mu \mathrm{g})$ at $4{ }^{\circ} \mathrm{C}$ for $2 \mathrm{hr}$. Beads were washed twice in buffer 1 consisting of $0.4 \%$ Nonidet $\mathrm{P}-40$ and (in $\mathrm{mm}$ ) $500 \mathrm{NaCl}, 10$ triethanolamine, $\mathrm{pH}$ 7.6, 5 EGTA, 5 EDTA, $1 \mathrm{Na}$ orthovanadate, 1 phenylmethylsulfonyl fluoride (PMSF), and then twice in buffer 1 supplemented with $50 \mathrm{~mm} \mathrm{NaCl}$. At this stage, the beads were either used in kinase assays or subjected to SDS-PAGE. Proteins binding to the fusions or GST alone were then detected by Western blotting. The antibodies used were as follows: anti-RACK-1 (mouse monoclonal; Transduction Laboratories, Lexington, KY) and anti-pan-PKC (rabbit polyclonal; Upstate Biotechnology, Lake Placid, NY). PKC-specific isoform antisera against the: $\alpha, \beta I I, \gamma, \delta, \epsilon, \zeta, \eta$, and $\theta$ isoforms have been described previously (Kiley and Parker, 1995). Blots were visualized using ECL (Pierce, Rockford, IL).

In vitro phosphorylation. To analyze the capability of associating kinases to phosphorylate bound $\mathrm{GABA}_{\mathrm{A}}$ receptor subunit intracellular domains, adult rat brain lysate was adsorbed with fusion proteins and washed as above. Beads were then washed in kinase buffer (in mM: 20 Tris, pH 7.4, $20 \mathrm{MgCl}_{2}, 1$ EDTA, 1 EGTA, 1 ouabain, $1 \mathrm{Na}$ orthovanadate, $0.1 \mathrm{DTT}$, and $2 \mathrm{MnCl}_{2}$ ) and then incubated at $30^{\circ} \mathrm{C}$ for up to $30 \mathrm{~min}$ in kinase buffer containing 3-30 $\mu \mathrm{Ci} \gamma^{32} \mathrm{P}$-ATP at a final concentration of $20 \mu \mathrm{M}$ (Amersham, Arlington Heights, IL). Beads were then pelleted, and bound material was separated by SDS-PAGE followed by autoradiography. To characterize the copurifying kinase activity, assays were performed in the presence of various kinase inhibitors; $0.1 \mu \mathrm{M}$ PKA inhibitor/Walsh peptide (Promega, Madison, WI), $1 \mu \mathrm{M}$ Cam KII inhibitor W7, (Calbiochem, La Jolla, CA) 0.1-0.5 $\mu \mathrm{M}$ PKC inhibitor peptide (19-36; Calbiochem).

Quantification of kinase activity interacting with $G A B A_{\mathrm{A}}$ receptor subunits. To analyze the level of kinase activity copurifying with each subunit, kinase assays were performed as above but in the presence of a core substrate peptide derived from neurogranin residues $28-43$ (NG 28-43; Promega), a well characterized PKC substrate (Chen et al., 1993). The peptide was added to the reaction at a concentration of $50 \mu \mathrm{M}$ with or without $\mathrm{PKC}_{(18-36)}$ inhibitor peptide $(10 \mu \mathrm{M})$ under the conditions described above. The reaction was stopped by adding an equal volume of ice-cold $150 \mathrm{~mm} \mathrm{H}_{3} \mathrm{PO}_{4}$. The beads were then pelleted, and triplicate aliquots of the supernatant were spotted onto Whatman P-81 phosphocellulose filter papers. Papers were then washed with three $10 \mathrm{~min}$ changes of $150 \mathrm{~mm} \mathrm{H}_{3} \mathrm{PO}_{4}$. The papers were then dried and subjected to Cherenkov scintillation counting. For all experiments, values were for control reactions lacking substrate, or beads not exposed to lysate were subtracted as blanks. Under the conditions used, the rate of phosphorylation was linear with respect to time.

Phosphoamino acid analysis. Phosphoamino acid analysis was performed on excised gel slices as described previously (Moss et al., 1992a; McDonald and Moss, 1994). Phosphoprotein gel slices were rehydrated, washed, and digested with trypsin $(0.1 \mathrm{mg} / \mathrm{ml}$, Sigma) for $24 \mathrm{hr}$. Digested samples were then hydrolyzed with $6 \mathrm{~N} \mathrm{HCl}$ for $1 \mathrm{hr}$ at $100^{\circ} \mathrm{C}$. The resulting phosphoamino acids were then subjected to thin layer electrophoresis and subjected to autoradiography.
Filter overlay binding. Filter overlay assays were performed as described by $\mathrm{Li}$ et al. (1992). Filters containing GST-GABA ${ }_{\mathrm{A}}$ receptor fusion proteins encoding the intracellular domains of the $\alpha 1, \beta 1, \gamma 2 \mathrm{~s}$, and GST alone were probed with a GST-RACK-1 fusion protein produced in pGEX-2TK (Pharmacia), labeled via phosphorylation with the catalytic subunit of cAMP-dependent protein kinase (Promega) to a specific activity in excess of $10^{6} \mathrm{cpm} / \mu \mathrm{g}$. The PKC overlay assays were performed essentially as described by Ron et al. (1994) using PKC purified from rat brain, a generous gift from Rick Huganir (Johns Hopkins School of Medicine, Baltimore, MD). PKC- $\beta$ II was detected using an antisera specific for this PKC isoform (Marais and Parker, 1989; Kiley and Parker, 1995).

Preparation and labeling of cortical neurons. Cortices were dissected from embryonic day 19 rats, and the tissue was incubated in $0.25 \%$ trypsin in HEPES-buffered saline (HBSS; Life Technologies, Gaithersburg, MD) for $15 \mathrm{~min}$ followed by three 5 min washes in HBSS. The tissue was then dissociated by tituration with a fire-polished glass pipette. Cells were then plated on $0.1 \mathrm{mg} / \mathrm{ml}$ poly-L-lysine-treated $10 \mathrm{~cm}$ tissue culture dishes at a density of $10^{5}$ cells/ $/ \mathrm{cm}^{-2}$ and grown for $7 \mathrm{~d}$ before use. For metabolic labeling, the cultures were starved in methionine-free media for $30 \mathrm{~min}$ and then labeled with $\left[{ }^{35} \mathrm{~S}\right]$ methionine $(0.25 \mathrm{mCi} / \mathrm{ml}$; ICN Biochemicals, Costa Mesa, CA) for $12 \mathrm{hr}$, supplemented with 5\% normal media. For phorbol ester treatment, cells were exposed to $0.1 \mu \mathrm{M}$ $\mathrm{PDBu}$ at $37^{\circ} \mathrm{C}$ for $20 \mathrm{~min}$ before lysis.

Immunoprecipitation. Cortical neurons were solubilized in a buffer containing 1\% 3-[(3-cholamidopropyl)dimethylammonio]-1-propanesulfonic acid (CHAPS) and (in $\mathrm{mm}$ ) $150 \mathrm{NaCl}, 10$ triethanolamine, $\mathrm{pH} \mathrm{7.6,5}$ EGTA, 5 EDTA, $50 \mathrm{NaF}, 10 \mathrm{Na}$ pyrophosphate, $1 \mathrm{Na}$ orthovanadate, 100 PMSF, and $10 \mu \mathrm{g} / \mathrm{ml}$ leupeptin, pepstatin, antipain, and aprotinin. Solubilized receptors were immunoprecipitated using a rabbit polyclonal antisera specific for the $\beta 1$ and $\beta 3$ subunits (Moss et al., 1992b; McDonald et al., 1998) coupled to protein A Sepharose. Precipitated material was then separated by SDS-PAGE followed by autoradiography or Western blotting using antibodies against PKC isoforms, RACK-1 or $\mathrm{BD} 17$, an antibody that recognizes the $\mathrm{GABA}_{\mathrm{A}}$ receptor $\beta 2$ and $\beta 3$ subunits. Alternatively, precipitated material was subject to in vitro kinase assays. Briefly, beads were washed extensively in kinase buffer before the addition of $\gamma^{32} \mathrm{P}$-ATP to a final concentration of $1.0 \mu \mathrm{M}$ and incubated at $30^{\circ} \mathrm{C}$ for $20 \mathrm{~min}$. Reaction products were then separated by SDS-PAGE and visualized by autoradiography.

\section{RESULTS}

\section{Phosphorylation of the $\beta 1$ subunit intracellular domain by brain extracts}

To identify molecules that interact with $\mathrm{GABA}_{\mathrm{A}}$ receptors and mediate phosphorylation, the intracellular domains of $\mathrm{GABA}_{\mathrm{A}}$ receptor subunits $\alpha 1, \beta 1, \beta 3$, and $\gamma 2 \mathrm{~S}$ were expressed as GST fusion proteins (Moss et al., 1992; McDonald and Moss 1994). Purified fusion proteins immobilized on glutathione were then exposed to detergent-solubilized brain extracts. After extensive washing, bound material was then subjected to an in vitro kinase assay and phosphorylation was assessed by SDS-PAGE (Fig. 1A). Using this regimen, $\beta 1$-GST and $\beta 3$-GST were found to be phosphorylated rapidly to high stoichiometry $(\sim 0.2 \mathrm{~mol} / \mathrm{mol})$. However, $\alpha 1-$ GST and $\gamma 2 \mathrm{~S}-\mathrm{GST}$ were found not to be significantly phosphorylated under identical conditions (Fig. 1). The GST backbone was also not phosphorylated in these assays (data not shown). Phosphorylated $\beta 1$-GST and $\beta 3$-GST were then subjected to phosphoamino acid analysis, which revealed that both subunit intracellular domains were phosphorylated on serine residues only (Fig. 1C).

Previous studies have revealed that the $\beta 1$ and $\beta 3$ subunits can be phosphorylated by PKC, PKA, Cam KII, and PKG (Moss et al., 1992a,b; Krishek et al., 1994; McDonald and Moss, 1997; McDonald et al., 1998). To determine if any of these kinases were binding to, and phosphorylating, $\beta 1-G S T$, kinase inhibitors were used. Walsh peptide, a specific inhibitor of PKA and W7, an inhibitor of Cam KII, were without effect on $\beta 1$-GST phosphorylation. However, phosphorylation of $\beta 1$-GST was drastically re- 

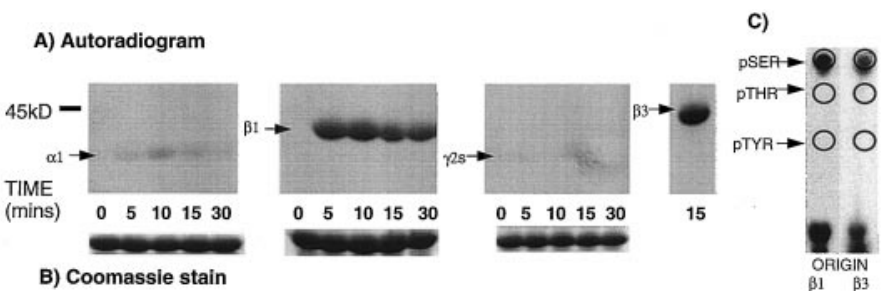

Figure 1. Serine-threonine protein kinases from neuronal extracts phosphorylate the intracellular domain of the $\beta$ subunits. $A, \alpha 1$-GST, $\beta 1$-GST, $\beta 3$-GST, or $\gamma 2$-GST were exposed to solubilized neuronal extracts. After extensive washing, bound material was subjected to an in vitro kinase assay for various time periods as indicated, and the reaction products were subjected to SDS-PAGE followed by autoradiography. Similar results were seen in at least three separate experiments. $B$, Represents Coomassie staining of gels containing the $\alpha 1$-GST, $\beta 1$-GST, and $\gamma 2$ S-GST fusion proteins demonstrating equivalence of loading. $C$, Gel slices containing the $\beta 1$-GST and $\beta 3$-GST phosphoproteins were subject to tryptic digestion followed by acid hydrolysis. The resulting phosphoamino acids were then separated by thin-layer chromatography and detected by autoradiography. The migration of phosphoserine $(p S E R)$, phosphothreonine $(p T H R)$, and phosphotyrosine $(p T Y R)$ are indicated.

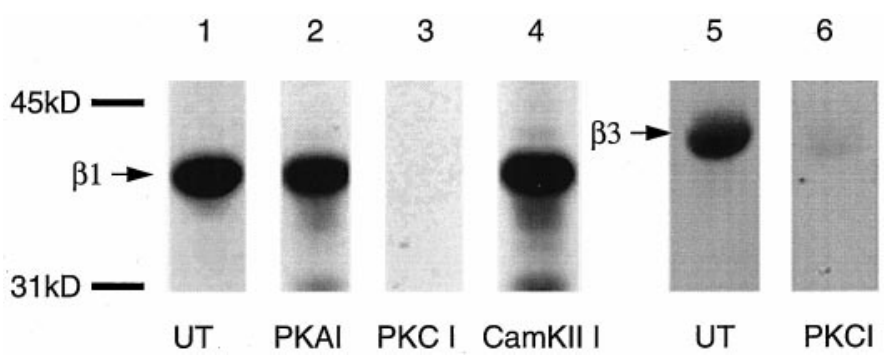

Figure 2. Protein kinase $\mathrm{C}$ inhibitors reduce neuronal extract serinethreonine-mediated phosphorylation of the intracellular domains of the $\mathrm{GABA}_{\mathrm{A}}$ receptor $\beta$ subunits. The phosphorylation of $\beta 1$-GST by neuronal extracts was analyzed with specific kinase inhibitors. Material associating with $\beta 1$-GST from neuronal extracts was subjected to in vitro kinase assays alone (UT; lane 1) or in the presence of a specific PKA inhibitor peptide (Walsh peptide, $0.1 \mu \mathrm{M}$; lane 2), a specific inhibitory peptide of PKC $\left(\mathrm{PKC}_{(19-36)}, 0.1 \mu \mathrm{M}\right.$; lane 3), or an inhibitor of Cam KII (W7, $1 \mu \mathrm{M}$; lane 4). Material associating with $\beta 3$-GST from neuronal extracts was subjected to in vitro kinase assays alone (UT; lane 5) or the presence of a specific peptide inhibitor of PKC $\left(\mathrm{PKC}_{(19-36)}, 0.1 \mu \mathrm{M}\right.$; lane 6$)$. Phosphorylation was assessed by SDS-PAGE followed by autoradiography. Similar results were seen in at least three independent experiments.

duced by the inclusion of a specific peptide inhibitor of PKC, $\mathrm{PKCI}_{(19-36)}$, at a concentration of $100 \mathrm{~nm}$ (Fig. 2). Phosphorylation of $\beta 3$-GST was also reduced by $\mathrm{PKCI}_{(19-36)}$ (Fig. 2).

To further explore this observation, mutated versions of $\beta 1$ GST and $\beta 3$-GST were included in these kinase assays. These studies focused on mutant fusion proteins in which in vitro and in vivo $\mathrm{PKC}$ substrates within the intracellular domains of the $\beta 1$ and $\beta 3$ subunits had been mutated to alanine residues. Previous studies have demonstrated that $\mathrm{S} 409$ in the $\beta 1$ subunit, and both S408 and S409 in $\beta 3$ are PKC substrates (Moss et al., 1992a,b; Krishek et al., 1994). Accordingly $\beta 1^{(\mathrm{S} 409 \mathrm{~A})}$-GST and $\beta 3^{(\mathrm{S} 408 /}$ 409A)_GST were exposed to neuronal extracts. Although there are additional serine residues in both the $\beta$ subunit intracellular domains, mutation of S409 in $\beta 1$ and S408/409 in $\beta 3$ abolished phosphorylation of $\beta 1$ and $\beta 3$-GST, respectively (Fig. 3). Importantly, phosphorylation of these residues by PKC has been previously shown to regulate the function of heteromeric receptors containing the $\beta 1$ or $\beta 3$ subunits (Lin et al., 1996; Moss and Smart, 1996; McDonald et al., 1998). Together these observations

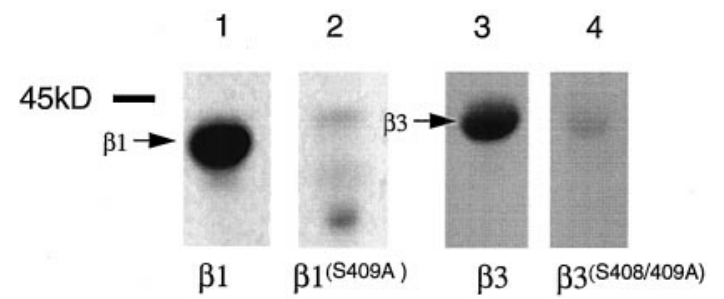

Figure 3. Serine-threonine protein kinases from neuronal extracts do not phosphorylate the intracellular domains of serine-to-alanine-mutated GABA $_{\mathrm{A}} \beta$ subunits. $\beta 1$-GST, $\beta 1^{(\mathrm{S} 409 \mathrm{~A})}$-GST, $\beta 3$-GST, and $\beta 3^{(\mathrm{S} 408 / 409 \mathrm{~A})}$ GST were exposed to neuronal extracts. Bound material was then subjected to an in vitro kinase assay. Phosphorylation was then assessed by SDS-PAGE followed by autoradiography. Similar results were seen in three independent experiments.

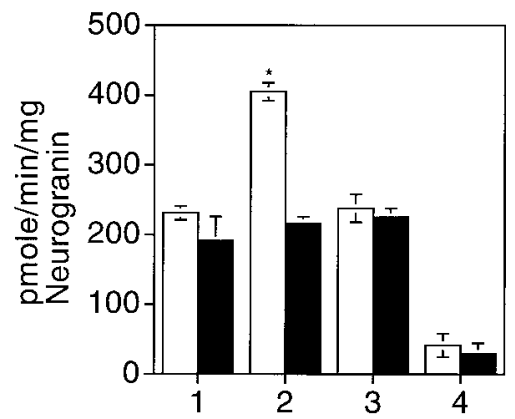

Figure 4. Phosphorylation of Neurogranin peptide by PKC activity specifically associating with $\beta 1$-GST. Material binding from adult rat brain extract to $\alpha 1$-GST (1), $\beta 1$-GST (2), $\gamma 2$-GST (3), or GST (4) alone was subject to an in vitro kinase assay using a substrate peptide derived from Neurogranin (Neurogranin 28-43, 50 $\mu \mathrm{M}$ ) in the presence (black bars) and absence (white bars) of $\mathrm{PKC}_{19-36}$ inhibitor peptide $(1 \mu \mathrm{M})$. Incorporation of ${ }^{32} \mathrm{P}$ into this peptide was then measured and normalized to the protein input, $n=3$ in each case. *Indicates significantly different from control $(p>0.05)$ as measured using the Student's $t$ test.

suggest that PKC can interact with and phosphorylate defined serine residues within the $\beta 1$ and $\beta 3$ subunit intracellular domains.

To control for possible differences in PKC substrate preferences between the various intracellular domains, material binding to the $\alpha 1$-GST, $\beta 1$-GST, $\gamma 2$-GST, and GST were all exposed to a PKC substrate peptide derived from neurogranin (Chen et al., 1993). The neurogranin peptide was phosphorylated by kinase activity binding to all three intracellular domains compared to GST alone (Fig. 4). The highest level of neurogranin phosphorylation was seen with $\beta 1$-GST. Importantly, $50 \%$ of the kinase activity associating with $\beta 1$-GST could be specifically inhibited by PKCI $_{(19-36)}(>0.05$; Fig. 4$)$; in contrast, the kinase activity associating with $\alpha 1$-GST and $\gamma 2$-GST was insensitive to $\mathrm{PKCI}_{(19-36)}$. Together our results further demonstrate that PKC can interact with the intracellular domains of $\mathrm{GABA}_{\mathrm{A}}$ receptor $\beta$ subunits. They also suggest another as yet unidentified serine-threonine kinase can also interact with the intracellular domains of the $\alpha 1$, $\beta 1$, and $\gamma 2 \mathrm{~S}$ subunits. However, none of these subunit intracellular domains appear to be phosphorylated by this kinase activity (Figs. 1-3).

\section{PKC isoforms specifically interact with $\mathrm{GABA}_{A}$ receptor $\boldsymbol{\beta}$ subunit intracellular domains}

To further characterize the interaction of $\mathrm{PKC}$ with $\mathrm{GABA}_{\mathrm{A}}$ receptors, fusion proteins were exposed to neuronal extracts, and 

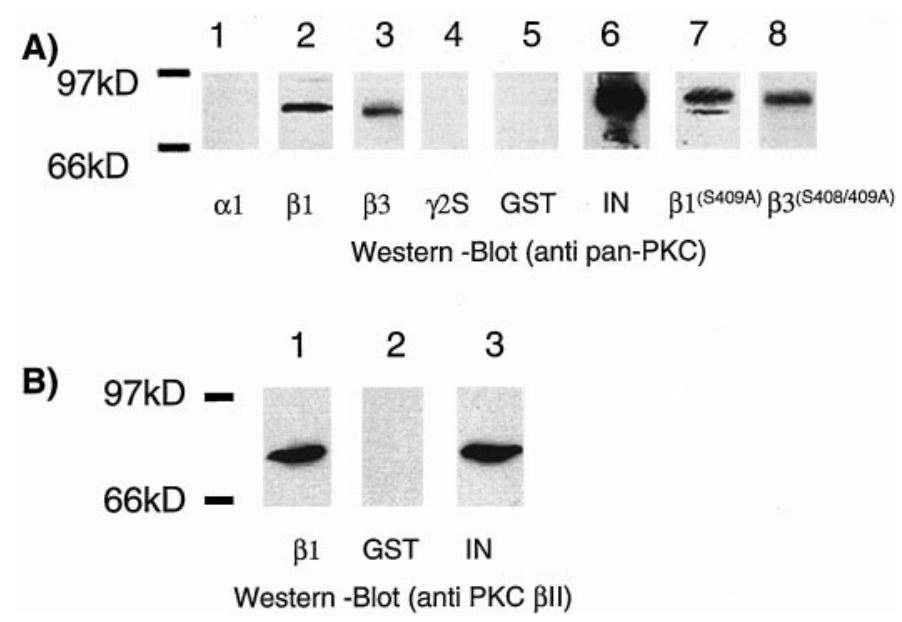

Figure 5. Solubilized neuronal protein kinase $\mathrm{C} \beta \mathrm{II}$ binds to the intracellular domain of the $\beta 1$ and $\beta 3$ subunits. $A, \alpha 1$-GST (lane 1), $\beta 1$-GST (lane 2), $\beta 3$-GST (lane 3), $\gamma 2 \mathrm{~S}-\mathrm{GST}$ (lane 4 ), GST (lane 5), $\beta 1^{\text {(S409A)-GST }}$ (lane 7 ), and $\beta 3^{\text {(S408/409A) }}$-GST (lane 8 ) were exposed to neuronal extracts, and after extensive washing bound material was subjected to Western blotting with a pan-PKC antibody. Lane $6(I N)$ represents $10 \%$ of the solubilized neuronal extract that was exposed to the respective fusion proteins. B, Material binding to $\beta 1$-GST (lane 1) or GST (lane 2) was probed with antisera against the $\beta$ II isoform of PKC via Western blotting. Lane $3(I N)$ represents $10 \%$ of the solubilized neuronal extract that was exposed to the respective fusion proteins.

bound material was then subjected to Western blotting using a pan-PKC antisera. This antisera recognizes the $\alpha, \beta \mathrm{I}, \beta \mathrm{II}$, and $\gamma$ isoforms of PKC. Using this antisera, a band of $82 \mathrm{kDa}$ was seen binding to $\beta 1-\mathrm{GST}$ and $\beta 3-\mathrm{GST}$, not to $\alpha 1-\mathrm{GST}, \gamma 2 \mathrm{~S}-\mathrm{GST}$, or GST alone (Fig. 5). Importantly, PKC could also be detected binding to both $\beta 1^{\text {(S409A) }}$-GST and $\beta 3^{\text {(S408/409A) }}$-GST. This suggests that $\beta 1$-GST and $\beta 3$-GST are not simply acting as PKC substrate-binding proteins (Newton, 1997).

To identify the isoform of PKC interacting with $\beta 1-G S T$, bound material was probed with isoform-specific antibodies. Using an antibody directed against PKC- $\beta$ II, a band of identical molecular mass was seen, as with the pan-PKC antisera (Fig. 5). In addition, small amounts of the $\alpha$ isoform of PKC were also detected binding to $\beta 1$-GST and $\beta 3$-GST (data not shown). In contrast, the $\beta, \gamma, \delta, \epsilon, \zeta, \eta$, and $\theta \mathrm{PKC}$ isoforms did not appear to interact with $\beta 1$-GST as determined by Western blotting, using isoform-specific antibodies.

Together these results suggests that PKC isoforms are capable of interacting and phosphorylating the intracellular domain of receptor $\beta$ subunits.

\section{PKC- $\beta$ II is capable of binding directly to $\mathrm{GABA}_{\mathrm{A}}$ receptor intracellular domains}

To test whether PKC- $\beta$ II could interact directly with $\mathrm{GABA}_{\mathrm{A}}$ receptor subunits, gel overlay assays were used. A range of receptor intracellular domains were transferred to a membrane and then exposed to PKC purified from rat brain that had been activated in vitro. Material binding to the $\mathrm{GABA}_{\mathrm{A}}$ receptor intracellular domains was then visualized with antisera directed against PKC- $\beta$ II. As a positive control, a GST fusion protein of the RACK- 1 was included in this assay. PKC- $\beta$ II could be seen binding directly to $\beta 1-\mathrm{GST}$ and also to RACK-1, but not to $\alpha 1$-GST or GST alone (Fig. 6). Importantly, Western blotting of the PKC preparation used for these experiments failed to detect RACK-1 (Fig. 6). Similar direct binding of PKC- $\beta$ II was also

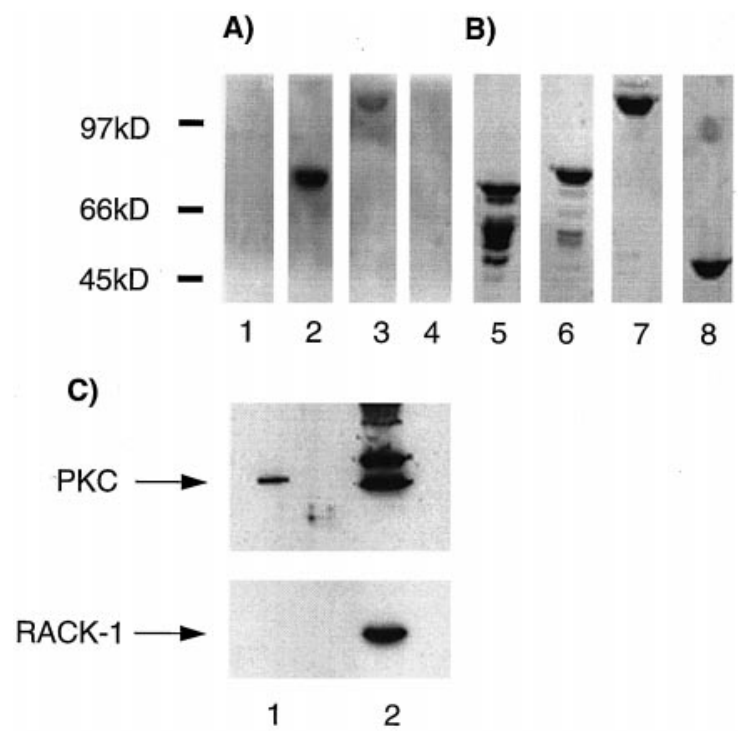

Figure 6. The $\beta \mathrm{II}$ isoform of PKC can bind directly to the intracellular domain of the $\beta 1$ subunit. $\alpha 1$-GST (lane 1), $\beta 1$-GST (lane 2), RACK-1GST (lane 3), or GST alone (lane 4 ) were transferred to a membrane and probed with PKC purified from rat brain. PKC binding to fusion proteins was then visualized with antisera against PKC $\beta$ II by Western blotting. Lanes 5-8 represent a Coomassie stain of an identical gel to show the equivalence in loading of the various proteins. $C$, The purified PKC preparation (50 ng; lane 1) used in the overlay assay and solubilized neuronal extract (100 $\mu \mathrm{g}$; lane 2$)$ were blotted with the pan-PKC antisera (top panel) and antibody specific for RACK-1.

seen with the intracellular domain of the $\beta 3$ subunit (data not shown). An alternative, but less likely explanation is that PKC activity could be directed to $\mathrm{GABA}_{\mathrm{A}}$ receptor intracellular domains by another unidentified kinase anchoring protein within the PKC preparation used for the overlay assay.

\section{RACK-1 associates with the $\beta 1$ and $\alpha 1$} intracellular domains

Previous studies have shown that the PKC- $\beta$ isoforms are targeted to substrates by anchoring proteins, such as RACK-1, a homolog of G-protein $\beta$ subunits (Ron et al., 1994; Pawson and Scott, 1997; Mochly-Rosen and Gordon, 1998). To examine whether RACK-1 has a role in targeting PKC activity to $\mathrm{GABA}_{\mathrm{A}}$ receptors, material binding to receptor intracellular domains of $\mathrm{GABA}_{\mathrm{A}}$ receptors from brain extracts was blotted using antisera specific for RACK-1. Using this antibody, a major band of $36 \mathrm{kDa}$ and a degradation product of $34 \mathrm{kDa}$ were seen in brain extract (Fig. 7A). The $36 \mathrm{kDa}$ band representing RACK-1 could be observed binding to $\beta 1-\mathrm{GST}$ but not to either $\alpha 1-\mathrm{GST}, \gamma 2 \mathrm{~S}-\mathrm{GST}$, or GST alone (Fig. $7 A$ ).

To determine if the interaction between RACK-1 and receptor intracellular domains was direct, gel overlay assays were used. Receptor GST fusions were transferred to a nitrocellulose membrane and probed with ${ }^{32} \mathrm{P}$-labeled RACK-1 expressed as a GST fusion protein. RACK-1 could be detected binding to $\beta 1$-GST and also $\alpha 1$-GST, but not to $\gamma 2$-GST or GST alone (Fig. 7B). This suggests that RACK-1 is capable of binding directly to the intracellular domains of the $\alpha 1$ and $\beta 1$ subunits in vitro.

\section{PKC and RACK-1 coimmunoprecipitate with neuronal $\mathrm{GABA}_{\mathrm{A}}$ receptors and phosphorylate receptor $\boldsymbol{\beta}$ subunits}

Our in vitro binding studies suggest that PKC- $\beta$ II and RACK-1 can bind to $\mathrm{GABA}_{\mathrm{A}}$ receptor $\beta$ subunit intracellular domains and 

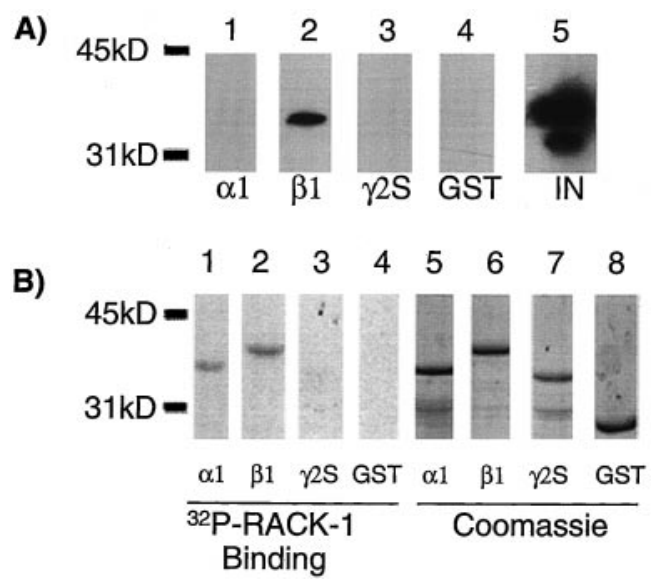

Figure 7. RACK-1 can bind directly to GABA receptor subunit intracellular domains. $A$, $\alpha 1$-GST (lane 1), $\beta 1$-GST (lane 2), $\gamma 2$-GST (lane 3), or GST alone (lane 4) were exposed to neuronal extracts, and after extensive washing, bound material was probed with an antibody for RACK-1. Lane 5 represents $10 \%$ of the input starting material. $B, \alpha 1$ GST (lane 1), $\beta 1$-GST (lane 2), $\gamma 2$-GST (lane 3), or GST (lane 4) fusion proteins were separated by SDS-PAGE and transferred to a membrane. Membrane was then probed with a radiolabeled GST-RACK-1 fusion protein. Bound RACK-1 was detected by autoradiography. Lanes 5-8 represent a Coomassie stain of an identical gel to show the equivalence in loading of the various proteins.

phosphorylate S409, a conserved phosphorylation site of critical importance for the regulation of $\mathrm{GABA}_{\mathrm{A}}$ receptor function (Moss et al., 1992b; Krishek et al., 1994; Lin et al., 1996; McDonald et al., 1998).

To examine the interaction of PKC with neuronal $\mathrm{GABA}_{\mathrm{A}}$ receptors, immunoprecipitation was used with an antisera specific for the $\beta 1$ and $\beta 3$ subunits (anti- $\beta 1 / 3$; Moss et al., 1992a; McDonald et al., 1998). Detergent-solubilized extracts from cultured cortical neurons that express the $\mathrm{GABA}_{\mathrm{A}}$ receptor $\alpha 1-5, \beta 1, \beta 3$, and $\gamma 2$ subunits (Benke et al., 1994; Macdonald and Olsen, 1994) were immunoprecipitated with anti- $\beta 1 / 3$ or control non-immune antisera. Anti- $\beta 1 / 3$ immunoprecipitated bands of $57,55,50$, and $47 \mathrm{kDa}$ from metabolically labeled cortical neurons (Fig. 8A). Material precipitating with anti- $\beta 1 / 3$ antisera was also Westernblotted with $\mathrm{Bd} 17$, an antibody specific for the $\mathrm{GABA}_{\mathrm{A}}$ receptor $\beta 2$ and $\beta 3$ subunits (Benke et al., 1994). Bd 17 recognized the 57 $\mathrm{kDa}$ band precipitated with anti- $\beta 1 / 3$ (Fig. 8 A, lanes 3,4 ). Given that most $\mathrm{GABA}_{\mathrm{A}}$ receptors only contain a single $\beta$ subunit isoform (Benke et al., 1994; Li and De Blas, 1997), the $57 \mathrm{kDa}$ band is therefore likely to represent the $\beta 3$ subunit. To determine if $\mathrm{PKC}$ was capable of binding to neuronal $\mathrm{GABA}_{\mathrm{A}}$ receptors, cortical cultures were treated with phorbol esters and then immunoprecipitated with anti- $\beta 1 / 3$ antisera. Precipitated material was then probed for PKC isoforms using pan-PKC antisera. A band of $82 \mathrm{kDa}$ corresponding to $\mathrm{PKC}$ could be detected precipitating with anti- $\beta 1 / 3$, but not with control antisera (Fig. $8 B$ ). Low levels of PKC immunoreactivity could be detected binding to $\mathrm{GABA}_{\mathrm{A}}$ receptors under basal conditions, (Fig. 8B, lane 1) however, this interaction was dramatically increased by phorbol ester treatment, suggesting that activated PKC isoforms interact with $\mathrm{GABA}_{\mathrm{A}}$ receptors in neurons (Fig. 8B, lane 2). Precipitated material was also probed for the presence of RACK-1. RACK-1 immunoreactivity could be detected coprecipitating with $\mathrm{GABA}_{\mathrm{A}}$ receptors (Fig. $8 C$ ).

To determine if $\mathrm{PKC}$ associating with $\mathrm{GABA}_{\mathrm{A}}$ receptors is
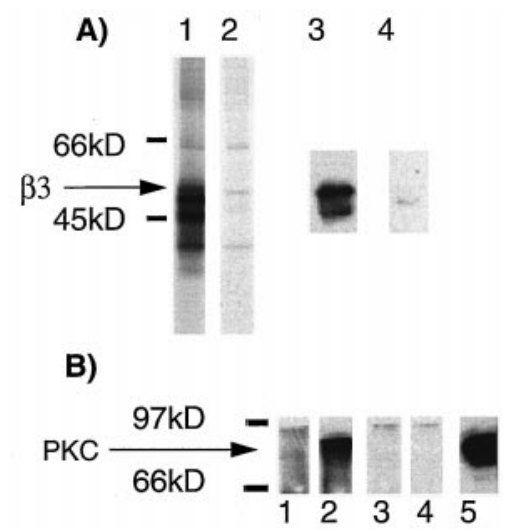

C)

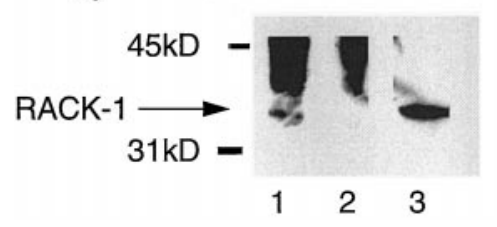

Figure 8. Both RACK-1 and PKC isoforms immunoprecipitate with $\mathrm{GABA}_{\mathrm{A}}$ receptors containing the $\beta 3$ subunit from cultured cortical neurons. $A$, Detergent-solubilized extracts from cortical neurons metabolically labeled with $\left[{ }^{35} \mathrm{~S}\right]$ methionine were immunoprecipitated with anti$\beta 1 / 3$ (lane 1) or control nonimmune $\operatorname{IgG}$ (lane 2) and separated by SDS-PAGE. Receptor subunits were visualized by autoradiography. In addition, material precipitated with anti- $\beta 1 / 3$ (lane 3) or control IgG (lane 4 ) was Western-blotted with a monoclonal antisera against the $\beta 2$ and $\beta 3$ subunits. $B$, Cortical cultures exposed to PDBu for 20 min (lanes 2, 4) or control cultures (lanes 1, 3) were precipitated with anti- $\beta 1 / 3$ (lanes 1, 2) or control IgG (lanes 3, 4). Precipitated material was then Western-blotted with a pan-PKC antisera. Lane 5 represents $10 \%$ of the material used for the immunoprecipitation. $C$, Cortical cultures exposed to PDBu for 20 min and precipitated with anti- $\beta 1 / 3$ (lane 1) or control IgG (lane 2) and Western-blotted with an antibody specific for RACK-1. Lane 3 represents $10 \%$ of the material used for the immunoprecipitation.

catalytically active, precipitated material was subjected to an in vitro kinase assay using ${ }^{32} \gamma$-ATP; the reaction products were then separated by SDS-PAGE. Phosphorylation of a major band of 57 $\mathrm{kDa}$ representing the $\beta 3$ subunit was observed using anti- $\beta 1 / 3$ antisera, but not control nonimmune sera (Fig. 9). In addition, a minor band of $55 \mathrm{kDa}$ was also phosphorylated. Phosphorylation of these bands was evident under basal conditions, consistent with the interaction of PKC with $\mathrm{GABA}_{\mathrm{A}}$ receptors seen in cortical neurons (Fig. 8). Phosphorylation of the 57 and $55 \mathrm{kDa}$ bands was enhanced by phorbol ester treatment (Fig. 9). In contrast, the specific PKC inhibitor PKCI ${ }_{(19-36)}$ completely abolished phosphorylation of the 57 and $55 \mathrm{kDa}$ bands (Fig. 9, lane 2).

Together, these results suggests that PKC isoforms and RACK-1 are closely associated with neuronal $\mathrm{GABA}_{\mathrm{A}}$ receptors. Furthermore, the PKC isoforms interacting with $\mathrm{GABA}_{\mathrm{A}}$ receptors are capable of phosphorylating receptor $\beta$ subunits.

\section{DISCUSSION}

$\mathrm{GABA}_{\mathrm{A}}$ receptors are of central importance in mediating fast synaptic inhibition in the brain. Given the pivotal role these receptors play in synaptic transmission, it is of fundamental importance to understand how these ion channels are regulated. One mechanism that has received considerable attention is direct receptor phosphorylation.

Studies on recombinant and neuronal receptors have demon- 


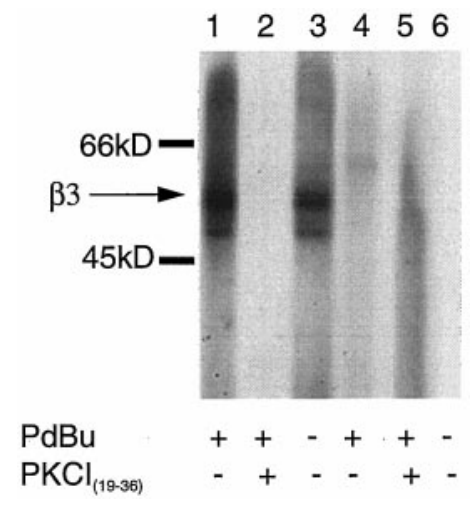

Figure 9. $\mathrm{PKC}$ isoforms associating with $\mathrm{GABA}_{\mathrm{A}}$ receptors in cortical neurons are capable of phosphorylating the receptor $\beta 3$ subunit. Cortical cultures were treated with $(+P d B u)$ or without $(-P d B u)$ and immunoprecipitated with anti- $\beta 1 / 3$ (lanes $1-3$ ) or control IgG (lanes 4-6). Precipitated material was then subjected to an in vitro kinase assay in the presence $(+P K C I)$ of absence of $\mathrm{PKC}_{(19-36)}$ inhibitor $(-P K C I)$ peptide, phosphorylation was assessed by SDS-PAGE and autoradiography.

strated that the receptor $\beta$ and $\gamma 2$ subunits are the substrates of a number of protein kinases (Moss and Smart, 1996). PKC for instance, has been shown to phosphorylate $\mathrm{S} 409$ in the $\beta 1$ and S408/409 in $\beta 3$ subunit (Moss and Smart, 1996; McDonald and Moss, 1997; McDonald et al., 1998). Likewise, PKC also phosphorylates residues in both the $\gamma 2 \mathrm{~L}$ (S327/343) and $\gamma 2 \mathrm{~S}$ (S327) subunits (Moss and Smart, 1996). Importantly, phosphorylation by PKC of these residues in the $\beta 1$ and $\gamma 2$ subunits can modulate the functional properties of recombinant receptors as demonstrated by site-directed mutagenesis (Moss and Smart, 1996). Phosphorylation produces diverse effects, from clear cut inhibitions using murine receptors (Kellenberger et al., 1992; Krishek et al., 1994) to enhancements with bovine receptors (Lin et al., 1994, 1996). These discrepancies may results from species of receptor expressed or differences in recording protocols and methodologies of kinase activation. Experiments using neuronal preparations have shown that PKC activity universally causes inhibition of $\mathrm{GABA}_{\mathrm{A}}$ receptor function (Moss and Smart, 1996).

To gain further insights into how kinases are targeted to $\mathrm{GABA}_{\mathrm{A}}$ receptors, we have probed brain lysates with GST fusion proteins encoding subunit intracellular domains. Using the intracellular domain of the $\beta 1$ and $\beta 3$ subunits, a kinase activity could be detected specifically binding to and phosphorylating these proteins. The major substrate of this kinase within the $\beta 1$ subunit intracellular domain was serine 409 , and S408/S409 within the $\beta 3$ subunit previously characterized functionally relevant phosphorylation sites for both PKA and PKC in receptor $\beta$ subunits (Moss et al., 1992a,b; McDonald and Moss, 1994, 1997; Krishek et al., 1994; Lin et al., 1994, 1996; McDonald et al., 1998). The kinase activity in neurons phosphorylating the $\mathrm{GABA}_{\mathrm{A}}$ receptor $\beta 1$ and $\beta 3$ subunit intracellular domains, was identified as being PKC because of its specific inhibition by $\mathrm{PKC}_{(19-36)}$ inhibitor peptide. PKC- $\beta$ II could be detected binding to $\beta$ subunit intracellular domains but not to those of the $\alpha 1$ or $\gamma 2$ subunits. The $\beta$ II isoform of $\mathrm{PKC}$ has previously been shown to be the major PKC isoform associated with the cytoskeleton (Tanaka et al., 1991). In addition, within the hippocampus PKC $\beta$ II is present in CA1 dendrites (Ase et al., 1988; Nicholls, 1997), consistent with a role for this $\mathrm{PKC}$ isoform in associating with and regulating the function of $\mathrm{GABA}_{\mathrm{A}}$ receptors. In addition to $\mathrm{PKC}$, another as yet unidentified serine-threonine kinase activity could also be de- tected binding to the intracellular domains of the $\mathrm{GABA}_{\mathrm{A}}$ receptor $\alpha 1, \beta 1$, and $\gamma 2 \mathrm{~S}$ subunits. This kinase activity did not appear to phosphorylate any of these subunit intracellular domains but was able to phosphorylate a peptide substrate from neurogranin (Chen et al., 1993). Interestingly, there have been reports of a serine-threonine protein kinase that copurifies with $\mathrm{GABA}_{\mathrm{A}}$ receptors on benzodiazepine affinity chromatography. This activity was found to be independent of activators of PKC, PKA, or Cam KII (Sweetnam et al., 1988; Bureau and Laschet, 1995). Clearly, further studies will be needed to clarify the role of this kinase activity with regard to $\mathrm{GABA}_{\mathrm{A}}$ receptor function.

The interaction of PKC with receptor $\beta$ subunit intracellular domains may be direct or mediated by anchoring proteins such as RACK-1 and A kinase-anchoring proteins (AKAPs) (Pawson and Scott, 1997; Mochly-Rosen and Gordon, 1998). PKC- $\beta$ II was able to bind directly to the $\mathrm{GABA}_{\mathrm{A}}$ receptor $\beta 1$ subunit intracellular domain, but not to those of the $\alpha 1$ or $\gamma 2$ subunits. Together, our observations suggest that interaction with $\beta$ subunits could be a general mechanism for targeting $\mathrm{PKC}$ activity to $\mathrm{GABA}_{\mathrm{A}}$ receptors. Interestingly, RACK-1 was also able to bind directly to the intracellular domain of the $\alpha 1$ and $\beta 1$ subunits. Previous studies have suggested that RACK-1 is of fundamental importance in mediating the binding of activated PKC- $\beta$ isoforms with substrates in myocytes (Mochly-Rosen and Gordon, 1998). In the case of $\mathrm{GABA}_{\mathrm{A}}$ receptors however, PKC- $\beta$ II can clearly bind to the intracellular domain of the $\mathrm{GABA}_{\mathrm{A}}$ receptor $\beta 1$ subunit independently of RACK-1. This may suggest that RACK-1 may play a differing role in the targeting of PKC activity to $\mathrm{GABA}_{\mathrm{A}}$ receptors. For instance, RACK-1 may increase the affinity of the interaction between $\mathrm{GABA}_{\mathrm{A}}$ receptors and $\mathrm{PKC}-\beta \mathrm{II}$, ensuring stoichiometrical phosphorylation (Ron et al., 1994; MochlyRosen and Gordon, 1998). By specifically blocking the binding of RACK-1 to $\mathrm{GABA}_{\mathrm{A}}$ receptors, it may be possible to address the role of RACK-1 in the regulation of receptor function by $\mathrm{PKC}$ phosphorylation.

To test the relevance of our observations using subunit intracellular domains, the interaction of PKC with neuronal $\mathrm{GABA}_{\mathrm{A}}$ receptors was analyzed using immunoprecipitation from extracts of cortical neurons. Using antisera against the $\beta 1$ and $\beta 3$ subunits, PKC and RACK-1 were detected coprecipitating with $\mathrm{GABA}_{\mathrm{A}}$ receptors from neuronal extracts. Furthermore, PKC activity associating with $\mathrm{GABA}_{\mathrm{A}}$ receptors was capable of phosphorylating a major protein of $57 \mathrm{kDa}$ that was identified as the $\beta 3$ subunit.

Together our observations suggest that in the brain $\mathrm{GABA}_{\mathrm{A}}$ receptors are intimately associated with $\mathrm{PKC}$. This association in the case of PKC- $\beta$ II is mediated via the direct interaction of this kinase with the receptor $\beta$ subunits. This interaction may serve to localize $\mathrm{PKC}$ activity to $\mathrm{GABA}_{\mathrm{A}}$ receptors in the brain, allowing the rapid regulation of receptor activity by cell signaling pathways that modify PKC activity. Such rapid regulation may be a primary means of modifying the efficacy of synaptic inhibition and may therefore be an important mechanism in generating synaptic plasticity.

\section{REFERENCES}

Ase K, Saito N, Shearman MS, Kikkawa U, Ono Y, Igarashi K, Tanaka C, Nishizuka Y (1988) Distinct cellular expression of $\beta$ I- and $\beta$ IIsubspecies of protein kinase $\mathrm{C}$ in rat cerebellum. J Neurosci 8: 3850-3856.

Benke D, Fritschy JM, Trzeciak A, Bannwarth W, Mohler H (1994) The distribution, prevalence and drug binding profile of $\mathrm{GABA}_{\mathrm{A}}$ receptors 
subtypes differing in the $\beta$ subunit variant. J Biol Chem 269 $27100-27107$.

Browning MD, Bureau M, Dudek EM, Olsen RW (1990) Protein kinase $\mathrm{C}$ and cAMP-dependent protein kinase phosphorylate the $\beta$ subunit of the purified $\gamma$-aminobutyric acid A receptor. Proc Natl Acad Sci USA 87:1315-1318.

Bureau MH, Laschet JJ (1995) Endogenous phosphorylation of distinct $\gamma$-aminobutyric acid type A receptor polypeptides by Ser/Thr and Tyr kinase activities associated with the purified receptor J Biol Chem 270:26482-26487.

Chen SJ, Klann E, Gower MC, Powell CM, Sessoms JS, Sweatt JD (1993) Studies with synthetic peptide substrates derived from the neuronal protein neurogranin reveal structural determinants of potency and selectivity for protein kinase C. Biochemistry 32:1032-1039.

Kapur J, Macdonald RL (1996) Cyclic AMP-dependent protein kinase enhances hippocampal dentate granule cell $\mathrm{GABA}_{\mathrm{A}}$ receptor currents. J Neurophysiol 76:2626-2634.

Kellenberger S, Malherbe P, Sigel E (1992) Function of the $\alpha 1 \beta 2 \gamma 2 \mathrm{~S}$ $\gamma$-aminobutyric acid type A receptor is modulated by protein kinase $\mathrm{C}$ via multiple phosphorylation sites. J Biol Chem 267:25660-25663.

Kiley SC, Parker PJ (1995) Differential localization of protein kinase C isozymes in U937 cells: evidence for distinct isozyme functions during monocyte differentiation. J Cell Sci 108:1003-1016.

Kirkness EF, Bovenkerk CF, Ueda T, Turner AJ (1989) Phosphorylation of $\gamma$-aminobutyric acid (GABA)/benzodiazepine receptors by cyclic AMP-dependent protein kinase. Biochem J 259:613-616.

Kofuji P, Wang JB, Moss SJ, Huganir RL, Burt DR (1991) Generation of two forms of the $\gamma$-aminobutyric acid A receptor $\gamma$-2 subunit in mice by alternative splicing. J Neurochem 56:713-715.

Krishek BJ, Xie X, Blackstone CD, Huganir RL, Moss SJ, Smart TG (1994) Regulation of $\mathrm{GABA}_{\mathrm{A}}$ receptor function by protein kinase $\mathrm{C}$ phosphorylation. Neuron 12:1081-1095.

Li M, De Blas A (1997) Co-existance of two $\beta$ subunit isoforms in the same $\mathrm{GABA}_{\mathrm{A}}$ receptor. J Biol Chem 272 16564-16569.

Li M, Jan Y, Jan L (1992) Specification of subunit assembly by the hydrophilic amino-terminal domain of the Shaker potassium channel. Science 257:1225-1229.

Lin YF, Browning MD, Dudek EM, Macdonald RL (1994) Protein kinase $\mathrm{C}$ enhances recombinant bovine $\alpha 1 \beta 1 \gamma 2 \mathrm{~L} \mathrm{GABA}_{\mathrm{A}}$ receptor whole-cell currents expressed in L929 fibroblasts. Neuron 13:1421-1431.

Lin YF, Angelotti TP, Dudek EM, Browning MD, Macdonald RL (1996) Enhancement of recombinant $\alpha 1 \beta 1 \gamma 2 \mathrm{~L} \gamma$-aminobutyric acid A receptor whole-cell currents by protein kinase $\mathrm{C}$ is mediated through phosphorylation of both $\beta 1$ and $\gamma 2 \mathrm{~L}$ subunits. Mol Pharmacol 50:185-195.

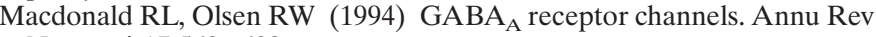
Neurosci 17:569-602.

McDonald BJ, Moss SJ (1994) Differential phosphorylation of intracellular domains of $\gamma$-aminobutyric acid type A receptor subunits by calcium/calmodulin type 2-dependent protein kinase and cGMPdependent protein kinase. J Biol Chem 269:18111-18117.

McDonald BJ, Moss SJ (1997) Conserved phosphorylation of intracellular domains of $\gamma$-aminobutyric acid type A receptor $\beta 2$ and $\beta 3$ subunits by cAMP dependent protein kinase, protein kinase $\mathrm{C}$, calcium/calmodulin type 2-dependent protein kinase and cGMP-dependent protein kinase. Neuropharmacology 36 13377-1385.
McDonald BJ, Amato A, Connolly CN, Benke D, Moss SJ, Smart TG (1998) Adjacent phosphorylation of $\mathrm{GABA}_{\mathrm{A}}$ receptor $\beta$ subunits determine regulation by cAMP-dependent protein kinase. Nat Neurosci 1:23-28.

Mochly-Rosen D, Gordon AS (1998) Anchoring proteins for protein kinase C: a means for isozyme selectivity. FASEB J 12:35-42.

Moss SJ, Doherty CA, Huganir RL (1992a) Identification of the protein kinase $\mathrm{A}$ and protein kinase $\mathrm{C}$ phosphorylation sites within the intracellular domains of the $\beta 1, \gamma 2 \mathrm{~S}$ and $\gamma 2 \mathrm{~L} \mathrm{GABA}_{\mathrm{A}}$ receptor subunits. J Biol Chem 267:14470-14476.

Moss SJ, Smart TG, Blackstone CD, Huganir RL (1992b) Functional modulation of $\mathrm{GABA}_{\mathrm{A}}$ receptors by cAMP-dependent protein phosphorylation. Science 257:661-665.

Moss SJ, Gorrie G, Amato A, Smart TG (1995) Modulation of GABA receptors by tyrosine phosphorylation. Nature 377:344-348.

Moss SJ, Smart TG (1996) Modulation of amino acid-gated ion channels by protein phosphorylation. In: International review of neurobiology, Vol 39 (Bradley RJ, Harris RA, Jenner P, eds), pp 1-52. San Diego: Academic.

Nicholls DG (1997) Protein kinase C and synaptic inhibition. In: Protein kinase C (Parker P, Dekker L, eds), pp 167-178. Berlin: Springer.

Newton CA (1997) Regulation of protein kinase C by cofactors. In: Protein kinase C (Parker P, Dekker L, eds), pp 25-39. Berlin: Springer.

Pawson T, Scott J (1997) Signaling through scaffold anchoring and adaptor proteins. Science 278:2075-2080.

Rabow LE, Russek SJ, Farb DH (1995) From ion currents to genomic analysis: recent advances in $\mathrm{GABA}_{\mathrm{A}}$ receptor research. Synapse 21:189-274.

Ron D, Chen CH, Caldwell J, Jamieson L, Orr E, Mochly-Rosen D (1994) Cloning of an intracellular receptor for protein kinase C: a homolog of the $\beta$ subunit of G-proteins. Proc Natl Acad Sci USA 91:839-843.

Smith DB, Johnson KS (1988) Single step purification of polypeptides expressed in $E$. coli as fusions with glutathione- $S$-transferase. Gene 67:31-40.

Sweetnam PM, Lloyd J, Gallombardo P, Malison RT, Gallager DW, Tallman JF, Nestler EJ (1988) Phosphorylation of the GABAa/benzodiazepine receptor $\alpha$ subunit by a receptor-associated protein kinase. J Neurochem 4:1274-1284.

Tanaka S, Tominaga M, Yasuda I, Kishimoto A, Nishizuka Y (1991) Protein kinase $\mathrm{C}$ in rat brain synaptosomes. $\beta \mathrm{II}$-subspecies as a major isoform associated with membrane-skeleton elements. FEBS Lett 294:267-270

Unwin N (1993) Neurotransmitter action: opening of ligand-gated ion channels. Cell [Suppl] 72:31-41.

Valenzuela CF, Machu TK, McKernan RM, Whiting P, VanRenterghem BB, McManaman JL, Brozowski SJ, Smith GB, Olsen RW, Harris RA (1995) Tyrosine kinase phosphorylation of $\mathrm{GABA}_{\mathrm{A}}$ receptors. Brain Res Mol Brain Res 1-2:165-172.

Whiting P, McKernan RM, Iversen L (1990) Another mechanism for creating diversity in $\gamma$-aminobutyric acid type A receptors: RNA splicing directs expression of two forms of $\gamma 2$ subunit, one of which contains a protein kinase $\mathrm{C}$ phosphorylation site. Proc Natl Acad Sci USA 87:9966-9970. 